\title{
Flow cytometric DNA analysis of parathyroid benign lesions
}

\author{
Agata Gawrychowska ${ }^{1}$, Grzegorz Kowalski', Małgorzata Nabrdalik', Grzegorz Buła' , Bożena Lackowska ${ }^{2}$, \\ Adam Bednarczyk', Marcin Werbowski', Joanna Polczyk' ${ }^{1}$, Jacek Gawrychowski ${ }^{1}$
}

${ }^{1}$ Department of General and Endocrine Surgery, Medical University of Silesia, Katowice, Poland

${ }^{2}$ Maria Sklodowska-Curie National Research Institute of Oncology, Krakow Branch, Poland

\begin{abstract}
Introduction: It is difficult to differentiate benign and malignant lesions just by histopathological evaluation due to lack of clear criteria of diagnosis. Moreover, the group of benign pathologies of parathyroids is not homogenous, and recurrence of symptoms of hyperparathyroidism after surgical management was also noted in this group. This complication is not always due to inappropriate surgical technique. The goal of this work was to find the relationship between cellular ploidy and proliferative activity of adenomas and hyperplasia of parathyroids and preoperative levels of calcium and parathormone in the serum of patients surgically treated for primary hyperparathyroidism. Material and methods: A total of 98 parathyroid glands were tested, of which $81(82.7 \%)$ were from female patients and $17(17.3 \%)$ from male; the age of the patients was from 22 to 82 years, with an average of 58 years.

Results: In resected glands pathological evaluation showed the following results: in $53(54.1 \%)$ adenoma was present, and in 45 (45.9\%) there was hyperplasia. Sixty-seven of the samples $(68.4 \%)$ were characterised as diploid and $31(31.6 \%)$ as aneuploid. There is important positive correlation $(r=0.34595 ; p=0.011)$ between the percentage of S-phase cells (\% SPF) and calcium levels measured prior to surgical resection of adenoma. The further analysis of patients with adenoma characterised by aneuploidy proved a statistically valid, positive correlation between $\% \mathrm{SPF}$ and ionised calcium levels in blood serum of patients both before $(\mathrm{r}=0.7189 ; \mathrm{p}=0.003)$ and after the surgical treatment $(\mathrm{r}=0.6313 ; \mathrm{p}=0.012)$.

Conclusions: 1. Benign lesions of parathyroid with ploidy indicates their heterogeneity. 2. In aneuploid benign adenomas of parathyroid glands an increased percentage of cells in S phase (\% SPF) correlates with a high level of calcium in serum pre- and post-parathyroidectomy. (Endokrynol Pol 2021; 72 (1): 44-50)
\end{abstract}

Key words: parathyroid benign lesions; flow cytometry; serum calcium level

\section{Introduction}

The most successful and only curative approach of treatment of primary hyperparathyroidism (PHPT) is radical surgical management - resection of one or many pathological parathyroid glands. Long-term results after this procedure are usually positive. The etiology of PHPT is very diverse, it ranges from benign lesions (adenomas and hyperplasia) to malignant proliferations (carcinoma). Unfortunately, it is very difficult to differentiate benign and malignant lesions just by histopathological evaluation due to lack of clear criteria of diagnosis [1-3]. The carcinoma is most commonly diagnosed if there is the presence of lesions, infiltration of neighbouring tissues and organs, the presence of metastasis in regional lymph nodes, and recurrence of hyperparathyroidism symptoms after treatment [4, 5]. On the other hand, the group of benign pathologies of parathyroids is not homogenous, and recurrence of symptoms of hyperparathyroidism after surgical management was also noted in this group. Furthermore, this complication is not always due to inappropriate surgical technique.

The goal of this work was to find the relationship between cellular ploidy and proliferative activity of adenomas and hyperplasia of parathyroids and preoperative levels of calcium and parathormone in the serum of the patients surgically treated for primary hyperparathyroidism.

\section{Material and methods}

Study group was confined to 98 consecutive patients surgically treated for PHPT from 1.07.2017 to 30.06.2018, with diagnosis of adenoma or hyperplasia. Patients qualified to the research did not have any pathologies in the remaining parathyroid glands, which was confirmed by histopathological examination. Two independent pathologists verified all histopathological samples. The data about diagnosis, qualification for surgical management, outcomes of treatment, and control postsurgical examination were obtained from medical archival documentation.

Cytofluorimetric examinations were done in the Maria Skłodowska-Curie National Research Institute of Oncology in Krakow, at the Department of Cancer Pathomorphology. Materials from fresh samples of excised glands from previously diagnosed patients 
with multiple endocrine neoplasm were excluded. Evaluation of ploidy and proliferation was made with the ModFit software. The histogram DNA classification based on the ploidy was performed in consistency with the works of Shankey et al. - DNA Cytometry Consensus Conference (1992) [6].

Diploid histograms were described when only one signal of fluorescence was observed, suitable for cells in G0/G1 phase. Additional fluorescence signals and visible G2/M phase were criteria to classify the histogram as aneuploid. The level of aneuploidy was given as the DNA index (DI), meaning the ratio of fluorescence intensity for abnormal cells in phase G0/G1 to fluorescence intensity for normal cells in phase G0/G1. For diploid cells the DI was 1.0.

Diploid histogram with coefficient variance (the width of fluorescence signal for normal cells in G0/G1 phase in half of its length) over $8 \%$ was considered unsuitable for analysis. For aneuploid histogram the percentage of cells in S phase was given only for aneuploid cells. The proliferation index (PI) states the sum of the percentage of cells in S, G2, and M phase.

\section{Statistical analysis}

StatSoft Inc. (2014) STATISTICA v.12. (data analysis software system) was used in statistical analysis. After determining the data distribution with Shapiro-Wilk test for data with normal distribution, the examined groups were compared with Student's t-test, and the Mann-Whitney test was used for data distribution other than normal.

For data with a normal distribution, Pearson's linear correlation was used to confirm the relationship between the parameters studied, and Spearman's rank order correlation was used for distribution other than normal.

The numerical amounts in the examined groups were compared using the ${ }^{2}$ test. The results are presented in the form of average, standard deviation, and minimum and maximum values, as well as absolute numbers and percentages.

\section{Results}

A total of 98 parathyroid glands were tested, of which 81 $(82.7 \%)$ were from female patients and 17 (17.3\%) from male; the age of the patients was from 22 to 82 years, with an average of 58 years. In resected glands pathological evaluation showed the following results: in 53 (54.1\%) adenoma was present and in $45(45.9 \%)$ hyperplasia. Sixty-seven of the samples $(68.4 \%)$ were characterised as diploid and $31(31.6 \%)$ aneuploid. Further information is presented in Table 1, which shows that in the adenoma group of 53 patients, and in 45 treated for hyperplasia, the average parathyroid hormone (PTH) and ionised calcium levels decreased to the normal value. We might ask the question whether determination of ploidy values on parathyroid benign lesions would alter current clinical practice. But DNA analysis does not differentiate between normal glands and adenoma or hyperplasia.

The study did not provide a statistically significant correlation between the percentage of cells in S phase (\%SPF) and the level of PTH and ionised calcium in the blood serum of patients in the whole group of benign lesions, which was measured both before and after the benign parathyroid lesion removal surgery (Fig. 1A-D).

After the analysis of the study, there was no evident correlation between \% SPF and PTH levels in the serum, measured pre- and post-operatively in patients with adenoma. (Fig. 2 A, B). Whereas, there was a significant positive correlation $(\mathrm{r}=0.34595 ; \mathrm{p}=0.011)$ between $\%$ SPF and calcium levels measured prior to surgical resection of adenoma. The correlation was not observed after the surgical procedure (Fig. 2C, D).

By contrast, after surgical resection of hyperplasia, the correlation between \% SPF, PTH, and calcium levels in serum was not proven, either before surgery or after (Fig. 3A-D).

The further analysis of patients with adenoma characterised by aneuploidy proved a statistically valid, positive correlation $(\mathrm{r}=0.7189 ; \mathrm{p}=0.003)$ between $\%$ SPF and ionised calcium levels in blood serum of patients both before and after the surgical treatment $(\mathrm{r}=0.6313 ; \mathrm{p}=0.012)$ (Fig. 4A, B).

On the other hand, such a correlation was not observed in analysis of PTH levels in the serum of the patients (Fig. 4C, D).

There was also no significant correlation between \% SPF and ionised calcium and PTH levels in blood serum before or after surgical management in patients with diploid adenoma (Fig. 5A-D).

\section{Discussion}

Parathyroid gland pathologies are very difficult to differentiate owing to the fact that there is no certain histopathological guidance or criteria for their diagnosis. Today's method of analysis of samples under the microscope and classification the pathology upon the presence of fibrous capsule, fibrous trabeculae, mitotic figures, and invasion of vessels/capsule is insufficient. [1-4]. Furthermore, the differentiation between parathyroid carcinoma, atypical adenoma, typical adenoma, and hyperplasia is practically impossible [5].

In case of atypical adenoma, the tumour has some characteristics of carcinoma and adenoma, but definitive diagnosis cannot be made upon the absence of some carcinoma features. A promising tool to help with diagnosis is cytofluorometry. Although due to the time consuming, expensive studies its use is limited [7,8].

Even though it has been established that diagnosed aneuploidy by cytofluorometry is quite a good indicator for malignancy in some cases of solid tumours and generally is connected with worse prognosis [9-11], unfortunately the data of usage of this modality in cases of parathyroid pathologies are sparse and hence are controversial [12-13].

It has been shown that there is a close relationship between DNA ploidy and tumour biological nature [2]. Although aneuploidy is connected with potential malignancy and is a bad prognostic factor, it is not an unequivocal indicator of carcinoma. In diagnosed 
Table 1. Patients characteristics

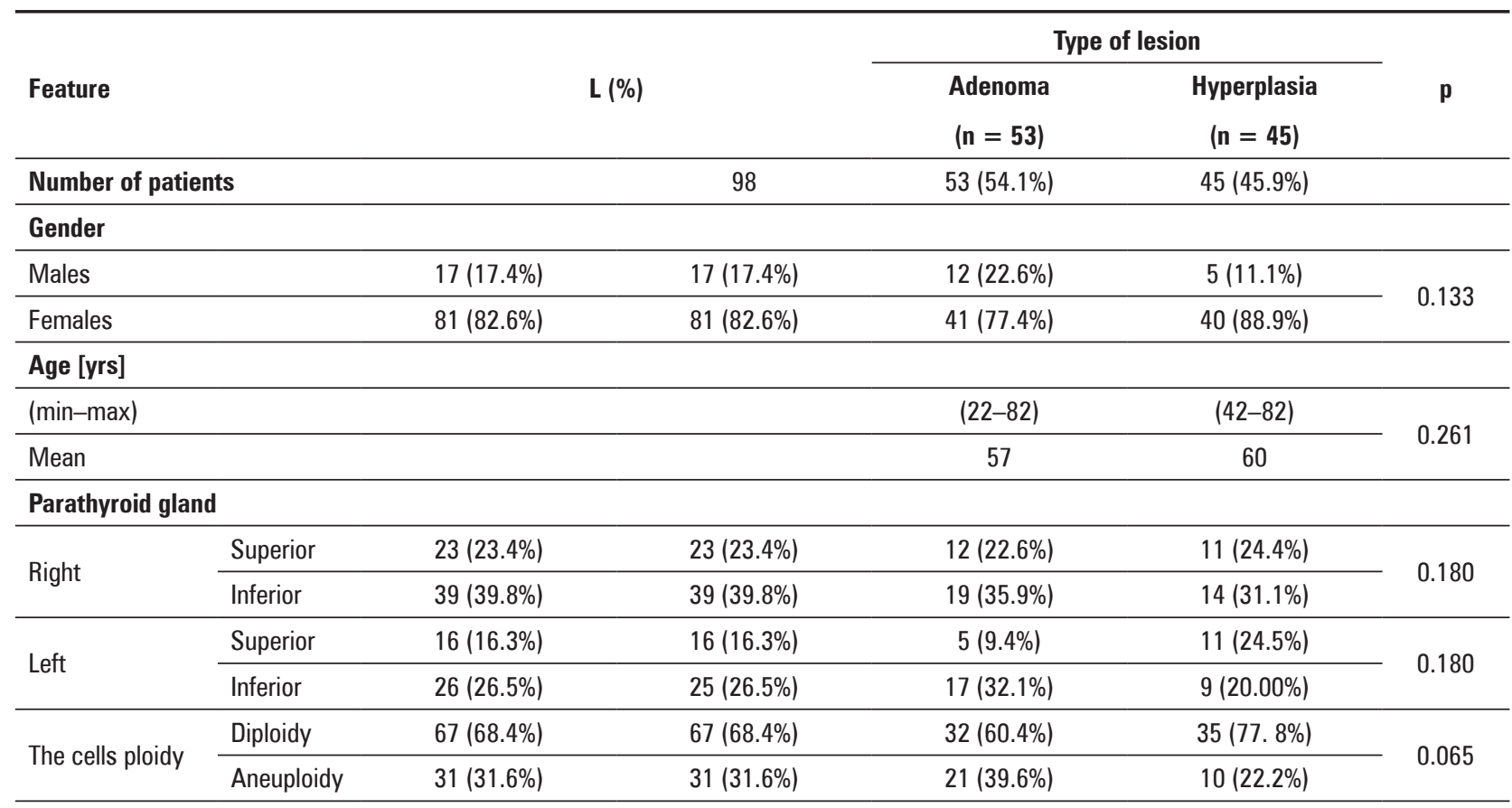

\begin{tabular}{|c|c|c|c|c|c|}
\hline \multicolumn{6}{|c|}{ DNA index in aneuploid lesions } \\
\hline & $<1$ & 8 & 6 & \multicolumn{2}{|l|}{2} \\
\hline & $>1-1.5$ & 12 & 8 & \multicolumn{2}{|l|}{4} \\
\hline & $>1.5$ & 11 & 7 & \multicolumn{2}{|l|}{4} \\
\hline \multicolumn{6}{|c|}{$\%$ of S phase } \\
\hline$(\min -\max )$ & & & $0.1-5.7$ & $0.1-31.5$ & \multirow{2}{*}{0.138} \\
\hline mean \pm SD & & & $1.39 \pm 1.69$ & $2.78 \pm 4.97$ & \\
\hline \multicolumn{6}{|l|}{ PTH } \\
\hline Before & & \multirow{2}{*}{ Mean \pm SD } & $423.62 \pm 594.2$ & $274.91 \pm 326.4$ & 0.138 \\
\hline After & & & $20.47 \pm 17.9$ & $21.26 \pm 22.1$ & 0.846 \\
\hline \multicolumn{6}{|l|}{$\mathrm{Ca}++$} \\
\hline Before & & \multirow{2}{*}{ Mean \pm SD } & & $1.51 \pm 0.07$ & 0.383 \\
\hline After & & & & $1.1 \pm 0.19$ & 0.378 \\
\hline
\end{tabular}

PTH — parathyroid hormone; $\mathrm{Ca}++$ — ionised calcium; SD — standard deviation

benign adenomas the percentage of aneuploidy varies between $5.4 \%$ and $60 \%$ [10-12], so DNA analysis suggests that some parathyroid adenomas and hyperplasia may contain a subset of tumours that could show biological malignancy if allowed to progress untreated.

In our research we observed aneuploidy in $32 \%$ of benign lesions. Considering only adenomas of parathyroids, the percentage was higher and on average was $40 \%$. In hyperplasia we observed aneuploidy in $22 \%$ of cases.

The historical study of Bengston and Irvin of healthy, hyperplastic, and adenomatous parathyroids showed in the first two types only lesions of normal character - diploidy, only in adenoma did they observe also aneuploidy. On the other hand, according to our research, aneuploidy can also be found in parathyroid hyperplasia [10].

On behalf of the research, Bowlby suggests that benign lesions can contain potentially malignant cells that can become active if the lesion is not resected [12]. In light of this, the estimation of the value of aneuploidy as an indicator of malignancy in histologically benign lesions is still inconclusive. It suggests that even histologically benign lesions with aneuploidy can be premalignant, and patients with this diagnosis should be preventively monitored for a longer time after surgical treatment $[14,15]$. A supporting factor for this approach is the fact the aneuploidy is an indicator of genetic instability of the cell $[16,17]$. It is currently believed that a histologically benign tumour with aneuploidy may be 

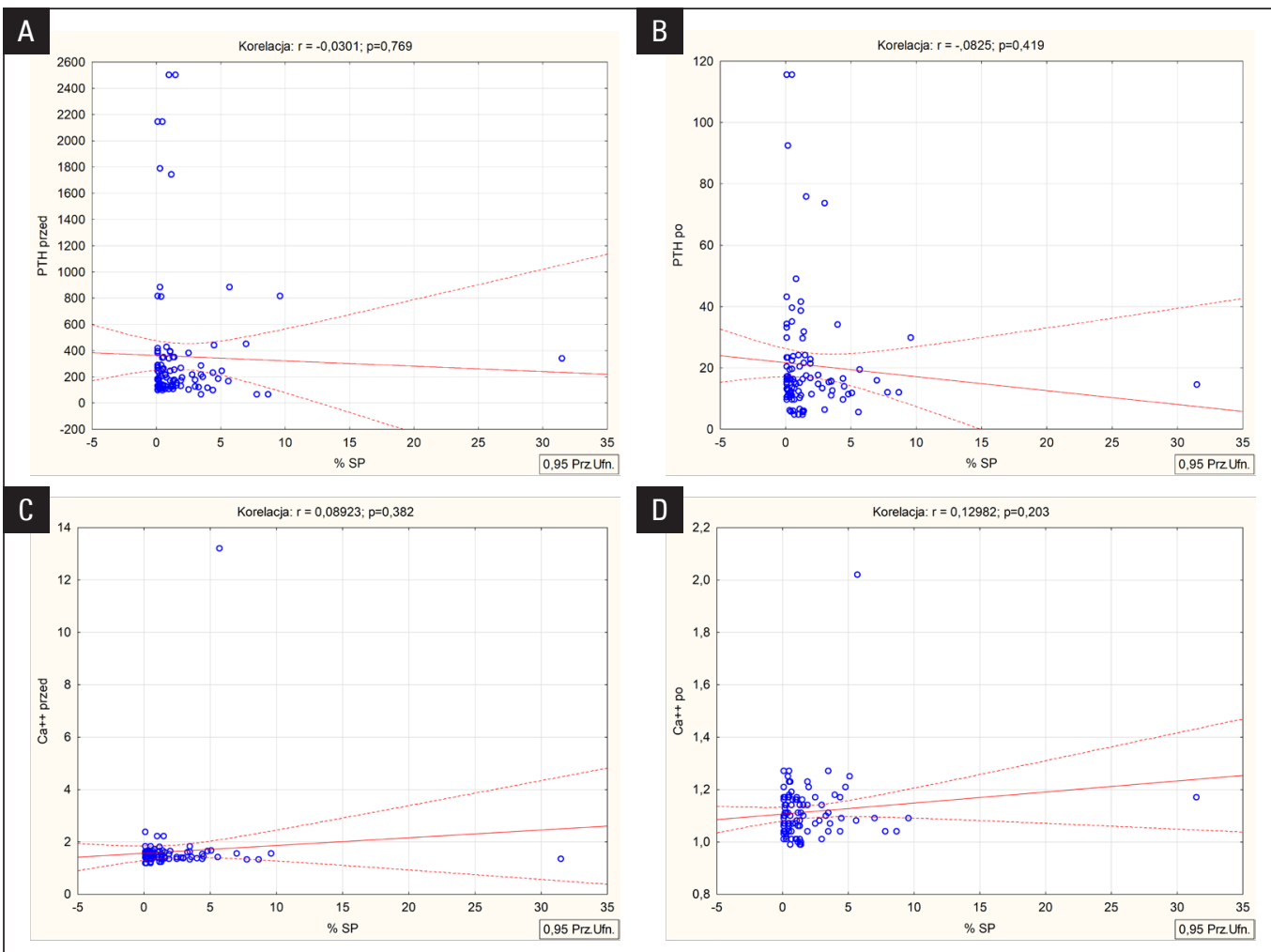

Figure 1A-D. Correlation between the percentage of cells in $S$ phase within benign lesions of parathyroid glands in blood serum of patients before $(\boldsymbol{A})$ and after $(\boldsymbol{B})$ surgery and ionised calcium before $(\boldsymbol{C})$ and after surgery $(\boldsymbol{D})$
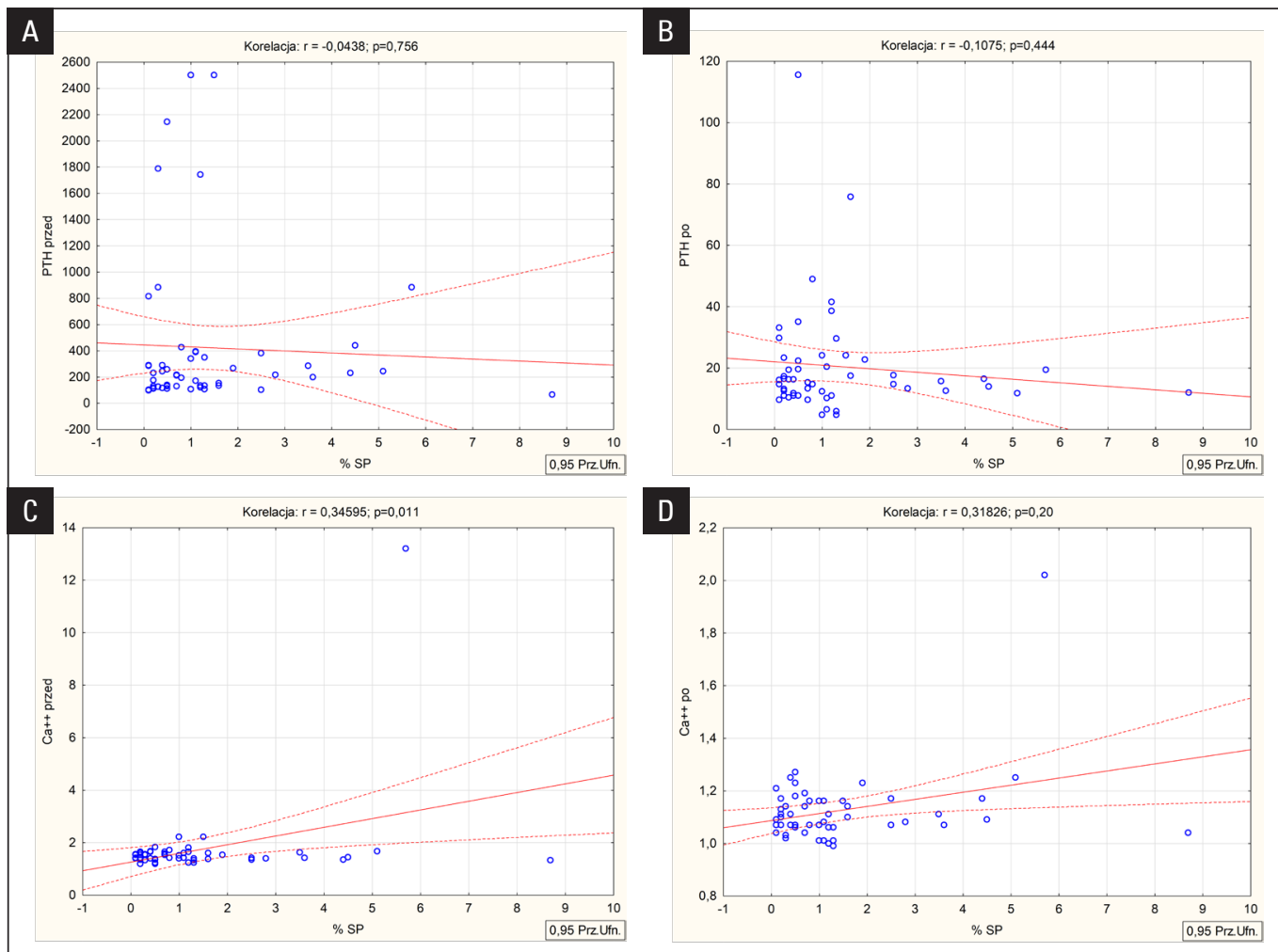

Figure 2A-D. Correlation between the percentage of cells in $S$ phase in adenoma of parathyroid glands patients' blood serum concentration of parathyroid hormone $(P T H)$ before $(\boldsymbol{A})$ and after $(\boldsymbol{B})$ surgery and the concentration of ionised calcium before $(\boldsymbol{C})$ and after surgery $(\boldsymbol{D})$ 

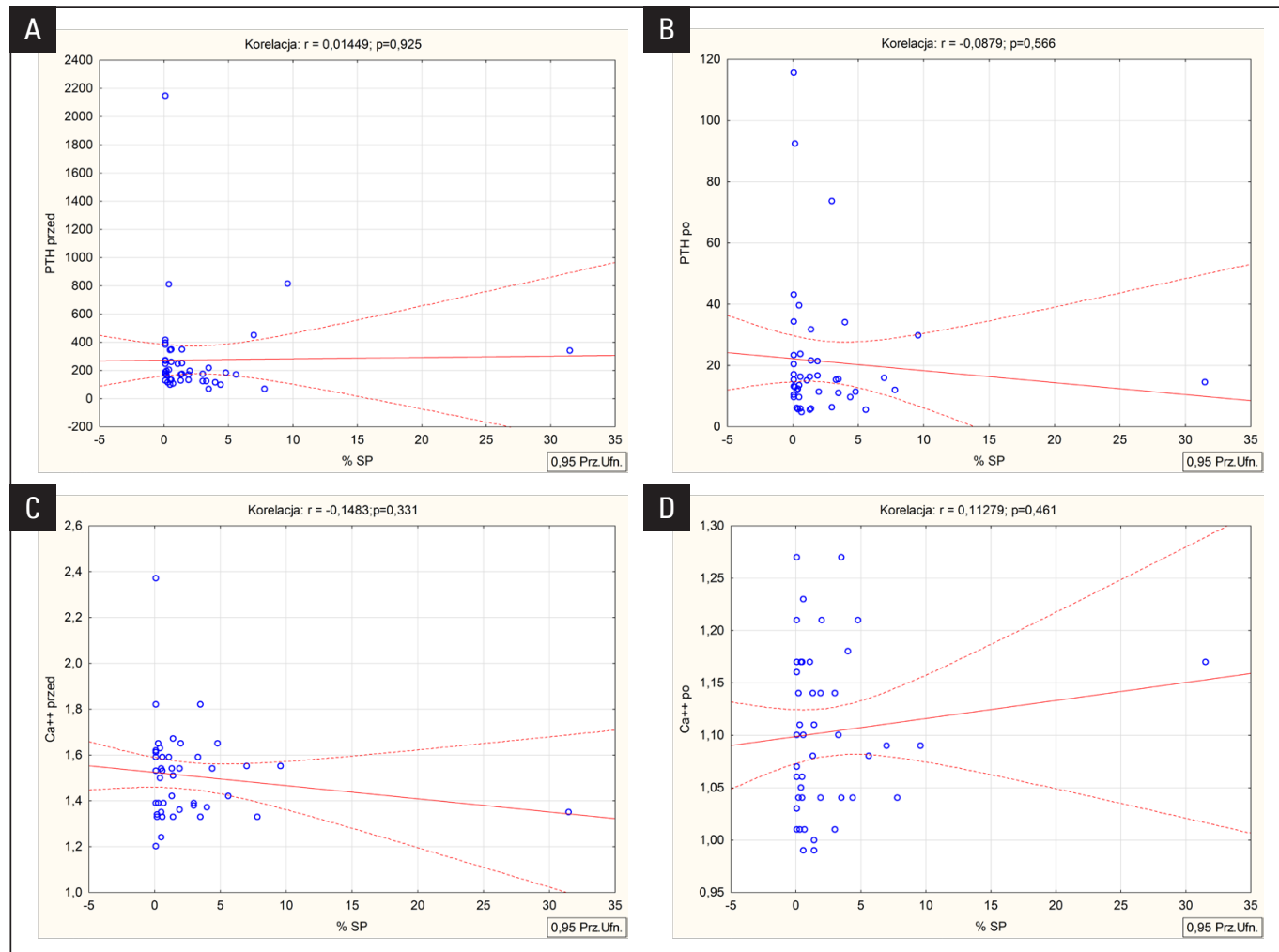

Figure 3A-D. Correlation between the percentage of cells in S phase in parathyroid hyperplasia and patients' blood serum concentration before $(\boldsymbol{A})$ and after $(\boldsymbol{B})$ surgery and ionised calcium before $(\boldsymbol{C})$ and after $(\boldsymbol{D})$ surgery
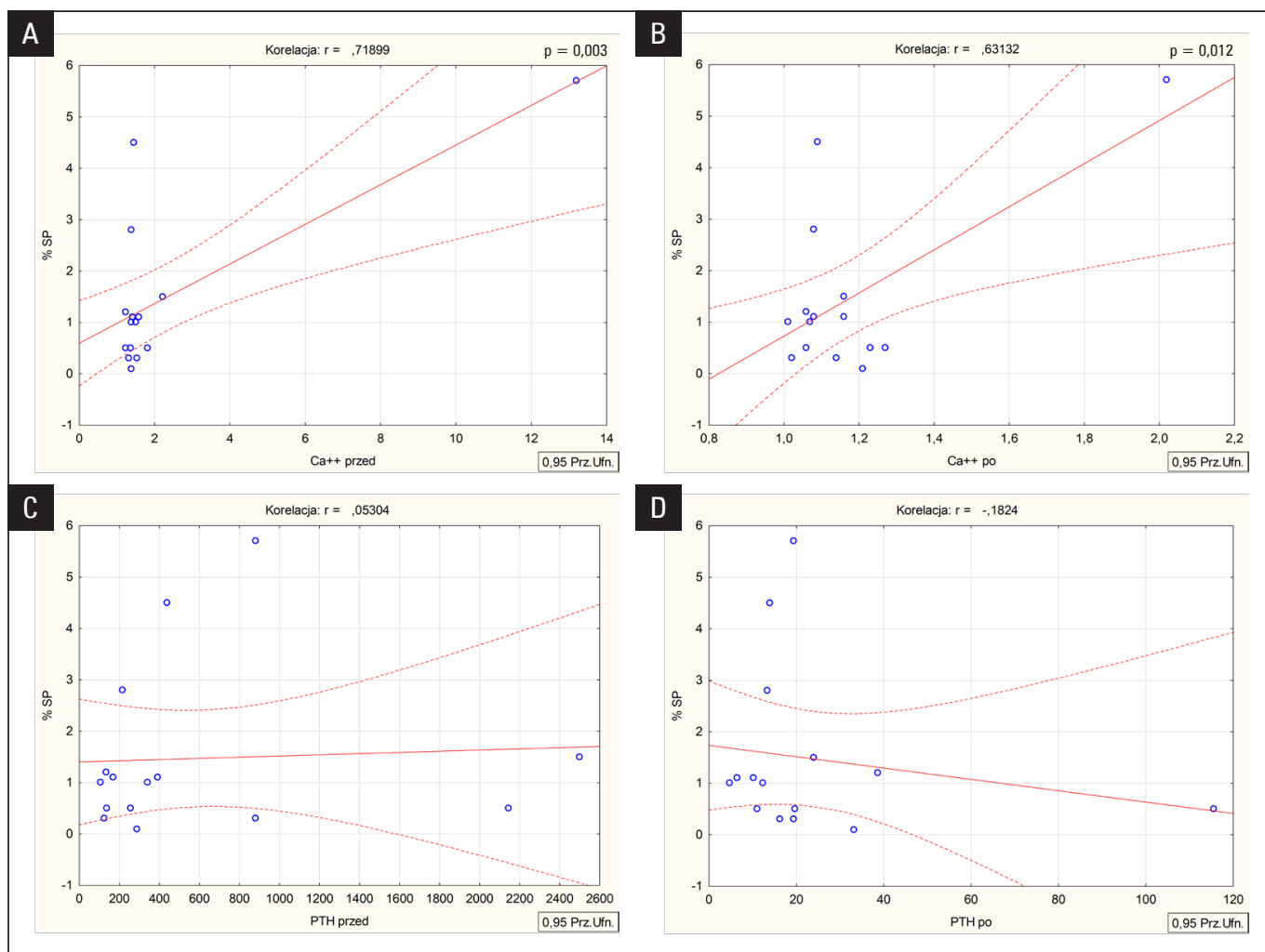

Figure 4A-D. Correlation between the percentage of cells in $S$ phase in aneuploid parathyroid adenomas and patients' blood serum concentration before $(\boldsymbol{A})$ and after $(\boldsymbol{B})$ surgery and the concentration of parathyroid hormone $(P T H)$ before $(\boldsymbol{C})$ and after $(\boldsymbol{D})$ surgery 

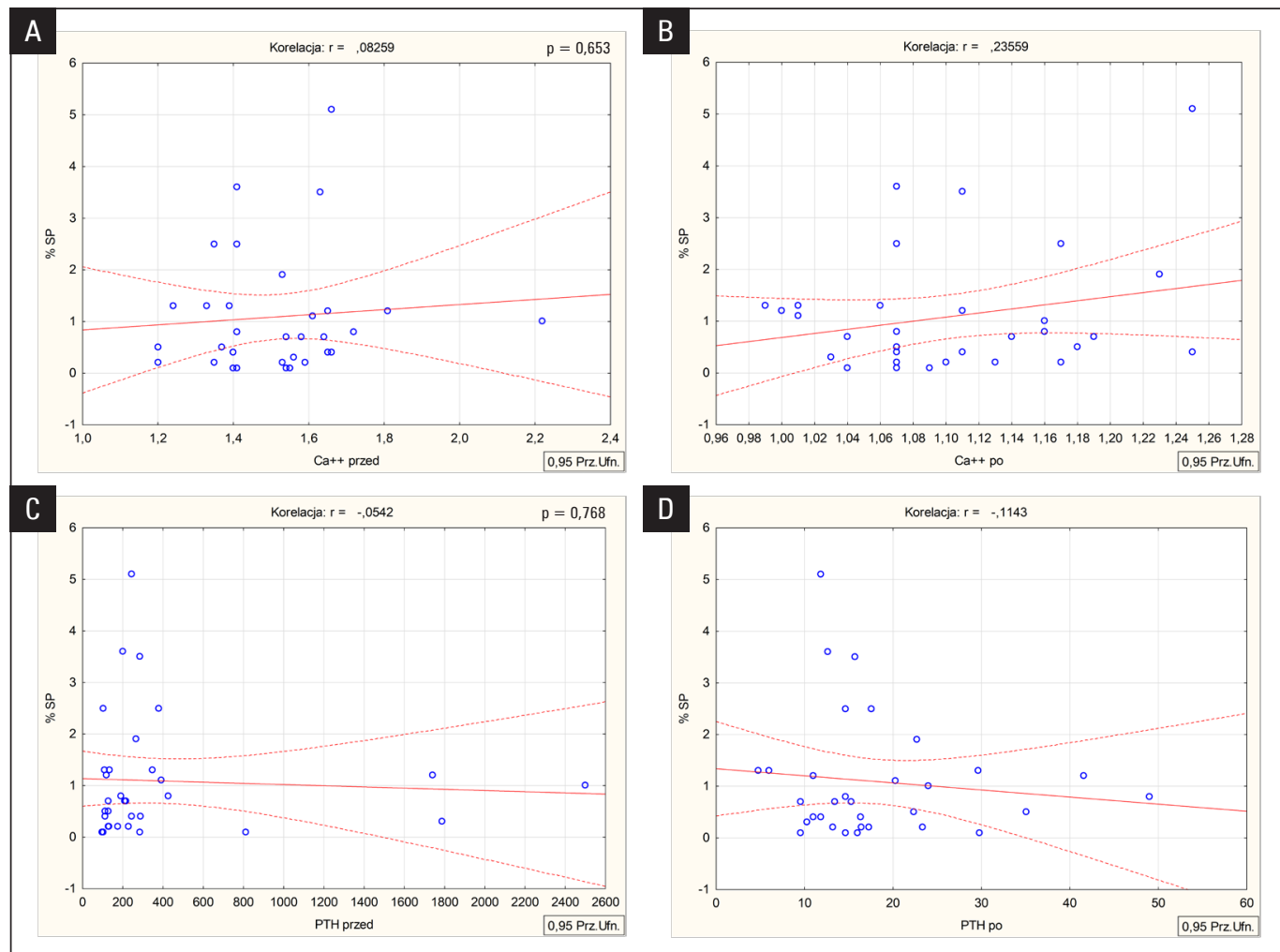

Figure 5A-D. Correlation between the percentage of cells in $S$ phase in diploid parathyroid adenomas and patients' blood serum concentrations before $(\boldsymbol{A})$ and after $(\boldsymbol{B})$ surgery and the concentration of parathyroid hormone $(\mathrm{PTH})$ before $(\boldsymbol{C})$ and after surgery $(\boldsymbol{D})$

premalignant and should be followed with heightened awareness for a long postoperative period.

Other authors in their studies proved limited value of DNA ploidy in the diagnosis of endocrine tumours. According to their results, diploid and aneuploid cell changes were found in healthy, hyperplastic, and carcinoid parathyroids [18-20].

Those results show that the tetraploidy that is observed in half of benign lesions and in some malignancies requires further analysis and study. Tetraploidy could be responsible for the speed of cellular proliferation $[21,22]$. Our study showed on average $30 \%$ of tetraploid changes in adenomas and hyperplasia, which confirmed the statements of other authors. From the results we can cautiously conclude that even though the cellular DNA measurements have limited use, the presence of aneuploidy (also tetraploidy) can increase the risk of development of carcinoma [23].

Rosen and Munchow confirmed that differentiation of healthy parathyroid from adenoma is practically impossible based only on cytofluorometry [13].

The higher concentration of calcium in patients' serum with diagnosis of carcinoma is quite relevant [24]. However, we also observed a positive correlation $(p=0.003)$ between the percentage of cells in $\mathrm{S}$ phase and levels of calcium in the group of patients with benign lesions. The correlation was also observed post surgically. The results indicate that an increase in cellular proliferation stimulates an increase in calcium levels in serum. The proliferative activity of the tumour is established by calculation of the percentage of cells in S phase [2,25]. Our study was able to define a subgroup of patients who showed DNA abnormalities that correlated with biochemical findings.

The increased number of cells in the S phase in solid tumours with aneuploidy is an established fact. Practically all authors agree that an increased percentage of cells in $S$ phase is connected with increased proliferative activity of the tumour $[2,25]$.

This correlation can testify the potential aggressiveness of aneuploid adenomas. This particular phenomenon can be a cause of increased calcium concentration in serum. In clinical practice, high levels of calcium are mostly found in parathyroid carcinomas [5, 25].

\section{Conclusions}

Benign lesions of parathyroid with ploidy indicates their heterogeneity.

In aneuploid benign adenomas of parathyroid glands an increased percentage of cells in $\mathrm{S}$ phase (\%SPF) correlates with a high level of calcium in serum pre- and post-parathyroidectomy. 


\section{References}

1. Adler JT, Sippel RS, Chen H. New trends in parathyroid surgery. Curr Probl Surg. 2010; 47(12): 958-1017, doi: 10.1067/j.cpsurg.2010.08.002, indexed in Pubmed: 21044730.

2. Segiet OA, Deska M, Michalski M, et al. Molecular profiling in primary hyperparathyroidism. Head Neck. 2015; 37(2): 299-307, doi: 10.1002/hed.23656, indexed in Pubmed: 24595969.

3. DeLellis R. Parathyroid tumors and related disorders. Modern Pathol. 2011; 24(S2): S78-S93, doi: 10.1038/modpathol.2010.132.

4. Duan K, Mete O. Parathyroid carcinoma: diagnosis and clinical implications. Turk Patoloji Derg . 2015; 31(Suppl 1): 80-97, doi: 10.5146/tjpath.2015.01316, indexed in Pubmed: 26177319

5. Medas F, Erdas E, Loi G, et al. Controversies in the management of parathyroid carcinoma: A case series and review of the literature. Int J Surg. 2016; 28: S94-S98, doi: 10.1016/j.ijsu.2015.12.040, indexed in Pubmed: 2670884 .

6. Shankey TV, Rabinovitch PS, Bagwell B, et al. Guidelines for implementation of clinical DNA cytometry. International Society for Analytical Cytology. Cytometry. 1993; 14(5): 472-477, doi: 10.1002/cyto.990140503, indexed in Pubmed: 8354117.

7. Kowalski GJ, Buła G, Żądło D, et al. Primary hyperparathyroidism. Endokrynol Pol. 2020; 71(3): 260-270, doi: 10.5603/EP.a2020.0028, indexed in Pubmed: 32797471.

8. Buła G, Kowalski G, Koziołek H. Surgical treatment of patients with primary hyperparathyroidism with a risk of hypercalcaemic crisis. Endokrynol Pol. 2020; 71(5), doi: 10.5603/EP.a2020.0032.

9. Levin KE, Chew KL, Ljung BM, et al. Deoxyribonucleic acid cytometry helps identify parathyroid carcinomas. J Clin Endocrinol Metab. 1988; 67(4): 779-784, doi: 10.1210/jcem-67-4-779, indexed in Pubmed: 3417849.

10. Bowly LS, DeBault LE, Abraham SR. Flow cytometric DNA analysis of parathyroid glands: Relationship between nuclar DNA and pathologic classifications. Am J Pathol. 1987; 128(2): 338-344, indexed in Pubmed: 3618729

11. Gawrychowski J, Tyczyński A, DanikA, et al. Wartość ploidii komórkowej w ocenie odległych wyników operacyjnego leczenia chorych z powodu gruczolakoraków żołądka. Pol Prz Chir. 2007; 79: 1364-1378.

12. Fujimoto $Y$, Obara T. How to Recognize and Treat Parathyroid Carcinoma. Surg Clin North Am . 1987; 67(2): 343-357, doi: 10.1016/s0039-6109(16)44188-5, indexed in Pubmed: 3551149.

13. Obara T, Fujimoto Y, Hirayama A, et al. Flow cytometric DNA analysis of parathyroid tumors with special reference to its diagnostic and prognostic value in parathyroid carcinoma. Cancer. 1990; 65(8): 1789-1793, doi: 10.1002/1097-0142(19900415)65:8<1789::aid-cncr2820650820>3.0.c o;2-n, indexed in Pubmed: 1969327.

14. Buła G, Truchanowski W, Koziołek H. A follow-up study of patients with MEN syndromes - five case reports. Endokrynol Pol . 2018; 69(2): 163-167, doi: 10.5603/EP.a2018.0020, indexed in Pubmed: 29952424.

15. Obara T, Fujimoto Y, Kanaji Y, et al. Flow cytometric DNA analysis of parathyroid tumors. Implication of aneuploidy for pathologic and biologic classification. Cancer. 1990; 66(7): 1555-1562, doi: 10.1002/1097-0142(19901001)66:7<1555::aid-cncr2820660721>3.0.c o;2-s, indexed in Pubmed: 2208008.

16. Howard S, Anderson C, Diels W, et al. Nuclear DNA density of parathyroid lesions. Pathol Res Pract. 1992; 188(4-5): 497-499, doi: 10.1016/s0344-0338(11)80044-0.

17. Mangili F, Sassi I, Schiaffino E, et al. [The use of flow cytometry in the study of parathyroid hyperplasia and adenomas]. Pathologica. 1992; 84: 459-465, indexed in Pubmed: 1491887.

18. Takada $\mathrm{M}$. he relationship between morphology and cell activy in hyperparathyreodism. Nippon Hinyokika Gakkai Zasshi. 1992; 83(11): 1774-1780, doi: 10.5980/jpnjurol1989.83.1774, indexed in Pubmed: 1479750.

19. Falkmer UG, Falkmer S. The Value of Cytometric DNA Analysis as a Prognostic Tool in Neuroendocrine Neoplastic Diseases. Pathol Res Pract. 1995; 191(4): 281-303, doi: 10.1016/s0344-0338(11)80883-6, indexed in Pubmed: 7479346.

20. Chryssochoos JT, Weber CJ, Cohen C, et al. DNA index and ploidy distinguish normal human parathyroids from parathyroid adenomas and primary hyperplastic parathyroids. Surgery. 1995; 118(6): 1041-9; discussion 1049, doi: 10.1016/s0039-6060(05)80112-6, indexed in Pubmed: 7491521.

21. Frierson HF. The need for improvement in flow cytometric analysis of ploidy and S-phase fraction. Am J Clin Pathol. 1991; 95(4): 439-441, doi: 10.1093/ajcp/95.4.439, indexed in Pubmed: 2014768.

22. Hedley DW. Flow cytometry using paraffin-embedded tissue: five years on. Cytometry. 1989; 10(3): 229-241, doi: 10.1002/cyto.990100302, indexed in Pubmed: 2653738

23. Buła G, Niemiec A, KoziołekH, et al. Przyczyny pierwotnej nadczynności przytarczyc — 27 lat leczenia chirurgicznego. Pol PrzChir. 2011; 83(Suppl 1): 30 .

24. Żebracka-Gala J, Waler J, Gawrychowski J, et al. Obniżona ekspresja genu JUN w gruczolakach przytarczyc. Pol PrzChir. 2009; 81: 845-810.

25. Niemiec A, Waler J, Koziołek H, et al. Bezpośrednie wyniki leczenia chirurgicznego pierwotnej nadczynności przytarczyc. Now Lek. 2007; 76(Suppl 1): 43. 